\title{
Psychicones: Visual Traces of the Soul in Late Nineteenth-Century Fluidic Photography
}

\author{
NICOLAS PETHES * \\ University of Cologne, IdSL 1, Albertus-Magnus-Platz, D-50923 Cologne, Germany
}

\begin{abstract}
The article discusses attempts to visualise the soul on photographic plates at the end of the nineteenth century, as conducted by the French physician Hippolyte Baraduc in Paris. Although Baraduc refers to earlier experiments on fluidic photography in his book on The Human Soul (1896) and is usually mentioned as a precursor to parapsychological thought photography of the twentieth century, his work is presented as a genuine attempt at photographic soul-catching. Rather than producing mimetic representations of thoughts and imaginations, Baraduc claims to present the vital radiation of the psyche itself and therefore calls the images he produces psychicones.

The article first discusses the difference between this method of soul photography and other kinds of occult media technologies of the time, emphasising the significance of its non-mimetic, abstract character: since the soul itself was considered an abstract entity, abstract traces seemed all the more convincing to the contemporary audience. Secondly, the article shows how the technological agency of photography allowed Baraduc's psychicones to be tied into related discourses in medicine and psychology. Insofar as the photographic plates displayed actual visual traces, Baraduc and his followers no longer considered hallucinations illusionary and pathological but emphasised the physical reality and normality of imagination. Yet, the greatest influence of soul photography was not on science but on art. As the third part of the paper argues, the abstract shapes on Baraduc's plates provided inspiration for contemporary avant-garde aesthetics, for example, Kandinsky's abstract paintings and the random streams of consciousness in surrealistic literature.
\end{abstract}

Keywords: Abstraction, Avant-garde, Experiment, Photography, Parapsychology, Occultism

According to Bruno Latour's analysis of modernity, the sciences are 'modern' mostly by an endeavour to exclude all theories and practices that question the rationality and purity of their methods, regardless of the possible affinity between these methods and

\footnotetext{
* Email address for correspondence: npethes@uni-koeln.de
} 
the ones they so decidedly rule out. ${ }^{1}$ This strategy applies especially within the history of psychology, since the human soul per se seems to be beyond empirical visibility and analysis. Johann Gottlob Krueger, for example, author of the first German treatise on experimental psychology in the mid-eighteenth century, assumed his readers would consider it a mere 'joke' to propose an empirical study of immaterial objects: 'Will we be able to place the spirits in an air pump, to behold their shapes through a magnifying glass, and to weigh their forces?' ${ }^{2}$ Moreover, in his critical revision of the Limits of Our Knowledge of Nature, Emil Heinrich Dubois-Reymond closed the case with his famous 'ignorabimus' by which he even denied the possibility of future insights into psychic processes. $^{3}$

The skepticism psychological research was confronted with from its very beginning was based on the lack of empirical data as well as methods, but it did not end scientific inquiries into the inexplicable emergence of cognition and emotion from physical matter. Early psychology embraced explorations of immaterial forces by definition and was therefore open to popular movements such as Mesmer's magnetism that we tend to refer to as a precursors of nineteenth-century spiritualism or occultism today, whereas they were considered scientific endeavours at the time. In other words, certain scientific theories and practices that we tend to call 'occult' and 'pre-modern' from today's point of view, were not developed in contrast to 'rational' and 'modern' science but were rather part of the (unknown or ignored) hybrid structure of the latter.

Choosing a Latourian perspective on the history of psychology, therefore, means not to conceive of 'irrational' discourses as something the study of the soul has to be 'purified' from. Rather, one has to account for the genuine hybridity of psychological research. This hybridity not only affects the soul as an (immaterial) object of study but also the (material) objects used for this study: in their attempt to turn an invisible object into empirical evidence, psychologists have to apply technological instruments that produce material traces from immaterial sources and thus create an 'epistemic thing' through the agency of a material device. ${ }^{4}$ These devices, usually considered mere appliances within a psychological laboratory, turn out to play an active part within the data gaining (or producing) process. The basic assumption of Actor-Network-Theory according to which 'Objects too have Agency' 5 is therefore especially obvious within a field where the human subjects' range of perception is as limited as in the case of studying the psyche.

In the laboratories of Wundt and his followers, these objects were instruments for measuring attention spans and response times. However, these devices only recorded the physical effects of psychical processes, not the soul itself. Therefore photography, in spite of its obvious limitations in representing invisible and immaterial objects, also became part of experimental set-ups in psychology during the late nineteenth and early twentieth centuries, exploring possibilities of media representations of the unrepresentable.

The pictures resulting from these experiments in photographing the soul may seem odd, untrustworthy and fabricated, but rather than questioning their authenticity, in the

\footnotetext{
${ }^{1}$ Bruno Latour, We Have Never Been Modern (Cambridge, MA: Harvard University Press, 1993).

2 Johann Gottlob Krüger, Versuch einer Experimental-Seelenlehre (Hemmerde: Halle/Helmstedt, 1756), 1. All translations from German are mine.

${ }^{3}$ Emil Heinrich Dubois-Reymond, Über die Grenzen des Naturerkennens (Leipzig: Veit, 1872), 464.

${ }^{4}$ Cf. Hans-Joerg Rheinberger, Toward a History of Epistemic Things: Synthesizing Proteins in the Test Tube (Stanford, CA: Stanford University Press).

${ }^{5}$ Bruno Latour, Reassembling the Social: An Introduction to Actor-Network-Theory (Oxford and New York: Oxford University Press, 2005), 63.
} 
following the focus will be on the way in which the more or less random or autonomous chemical reactions on the photographic plate were considered psychologically insightful at the time - regardless of the actual source of the visual traces on the plate. Therefore, I will not compare the claims of soul photographers to contemporary psychological theory but reconstruct the psychological concepts implicit in photographic experiments. My argument is going to be that the abstract nature of light effects on the plate supported the acceptance of soul photography precisely because it corresponded with the lack of empirical knowledge about the soul's actual nature. We may judge the resulting pictures as unscientific from today's point of view, but they disclose the closely woven network between scientists, publicists, media technologies and discursive orders that not only influenced crucial concepts of culture and art at the turn of the twentieth century but, as a network, is still active today.

In order to support this hypothesis, I will first trace the genealogy of soul-photography by distinguishing it from other modes of occult media technologies. As a second step, the technologies of fixating mental images on photographic plates will be located within contemporary debates about their scientific value, about possible deception and about their relation to psychiatric diagnoses of hallucination. In the third part, I will highlight the artistic implications of the mysterious shapes and figures as a field of genuine relevance for fluidic pictures, regardless of their acceptance in science: instead of deciding whether they actually are representations of the human soul, this perspective allows us to reconstruct the correspondence between psychological media and aesthetic theory in about 1900 .

\section{Beyond the Soul: Spirit, Fluid and Thought Photography}

Discourses on technological images have emphasised the ability of photography to visualise the invisible for a long time. ${ }^{6}$ Photography reveals details unrecognisable to the naked eye, ${ }^{7}$ and the appearance of people, animals, landscapes and buildings on early daguerrotypes bore a certain resemblance to spectral apparitions - a resemblance that was further underlined by the poor and shadowy quality of the pictures.

Accordingly, the new medium became an important part of the spiritualistic movement at the turn of the twentieth century. In its attempt to establish occult practices as empirical facts, this movement - most notably represented by the Society for Psychical Research (SPR), founded in London in 1882 - applied experimental methods and technological devices to document psychic phenomena such as telepathy, telekinesis and communication with the dead. Spirit photography had been popular among occultists ever since the image of a young girl had appeared next to a self-portrait by William H. Mumler in $1861-$ followed by the ghost of Abraham Lincoln that appeared on a photograph Mumler took of Lincoln's wife Mary Todd Lincoln in about $1869 .{ }^{8}$

The photographic plate, in its sensibility for details of the physical world indiscernible to the human eye, seemed to be receptive of transcendent influences, and there are numerous further examples for more or less corporeal apparitions on photographic pictures, for example, by Frederick Hudson or William Hope, from the late nineteenth and early

\footnotetext{
${ }^{6}$ Corey Keller, (ed.), Brought to Light. Photography and the Invisible 1840-1900 (Harvard: Harvard University Press, 2008).

${ }^{7}$ Carolin Artz, Indizieren, Visualisieren: Über die fotografische Aufzeichnung von Strahlen (Berlin: Kadmos, 2011).

${ }^{8}$ Clémont Chéroux, (ed.), The Perfect Medium. Photography and the Occult (New Haven: Yale University Press, 2004).
} 
twentieth centuries. ${ }^{9}$ When the SPR started to question the authenticity of Hope's spirit photography, the Society for the Study of Supernormal Pictures was established in London in 1918 to confirm the scientific value of the pictures. The society's vice president, one Sir Arthur Conan Doyle, published a treatise on The Case of Spirit Photography, with Corroborative Evidence by Experienced Researchers and Photographers in 1922.

Within the parapsychological movement, spirit photography merges the two meanings of the term 'medium': on the one hand, a medium is psychic person who establishes contact with the afterworld - that is, mediates between the visible world and the beyond. Because of this function, mediums seem depersonalised to the extent that they can be used as entities to communicate with absent or deceased people. On the other hand, as Stefan Andriopoulos argues in his study Possessed, this instrumental function links the psychic medium with another meaning of the word: a 'medium' is technological device that fulfils similar functions when it establishes acoustic contact across long distances or produces the visual appearance of absent people by means of photography or film. It is in this sense that the use of the term 'medium' for technological devices maintains the memory of pretechnological phantasies and visions of transcending the limits to human perception and human life. ${ }^{10}$

Thus, a close connection between occult practices, scientific research and media technologies is established at the turn of the century: telegraphy, cinematography and the gramophone, as well as the radio, take telecommunicative aim to present messages from the (temporal and spatial) beyond, from spiritual seances to scientific laboratories and popular culture. ${ }^{11}$ In this sense, spirit photography is a 'soul catcher' in a very literal sense as long as we think of the souls of the departed.

But is it also possible to use photography for actual pictures of the soul in the sense of a mental state or object of psychology? To answer this question, one has to remember another tradition of occult media technologies besides the popular fascination with spirit photography. This tradition is based on the invisible radiation that emerges from organic bodies that was first claimed by Franz Anton Mesmer in his (1734-1815) theory of animal magnetism at the end of the eighteenth century. The chemist and natural philosopher Carl von Reichenbach (1788-1869) developed this theory further in his concept of 'Odic' forces in the 1860s. Based on insights into electrical currents moving along processes within the nervous system, put forward by Luigi Galvani (1737-98) at the end of the eighteenth century, both theories claimed that living organisms produced a radiation that, as such, could be considered as a material expression of the living matter itself.

To the human eye, this radiation remained invisible. But, since photography had proven to be far more receptive to visual details than any organic apparatus, from the first plates produced by Daguerre in the late 1840s onwards, it was soon used as scientific proof for an otherwise highly speculative theory. Reichenbach, for example, presented a photograph of the 'Od' that showed an equilateral cross with geometric shapes in the four corners in $1862 .^{12}$ In 1896, Reichenbach's disciple, Ludwig Tormin, published a short treatise on Magic Radiation: How to Obtain Photographic Images Merely Through the

\footnotetext{
${ }^{9}$ Bill Jay, Cyanide \& Spirits: An-Inside-Out View of Early Photographs (Munich: Nazraeli-Press, 1991).

${ }^{10}$ Stefan Andriopoulos, Possessed: Hypnotic Crimes, Corporate Fiction, and the Invention of Cinema (Chicago, IL: Chicago University Press, 2008).

${ }^{11}$ Wolfgang Hagen, Radio Schreber: Der 'moderne Spiritismus' und die Sprache der Medien (Weimar: Verlag und Datenbank für Geisteswissenschaft, 2001).

12 Chéroux, op. cit. (note 8), 115.
} 


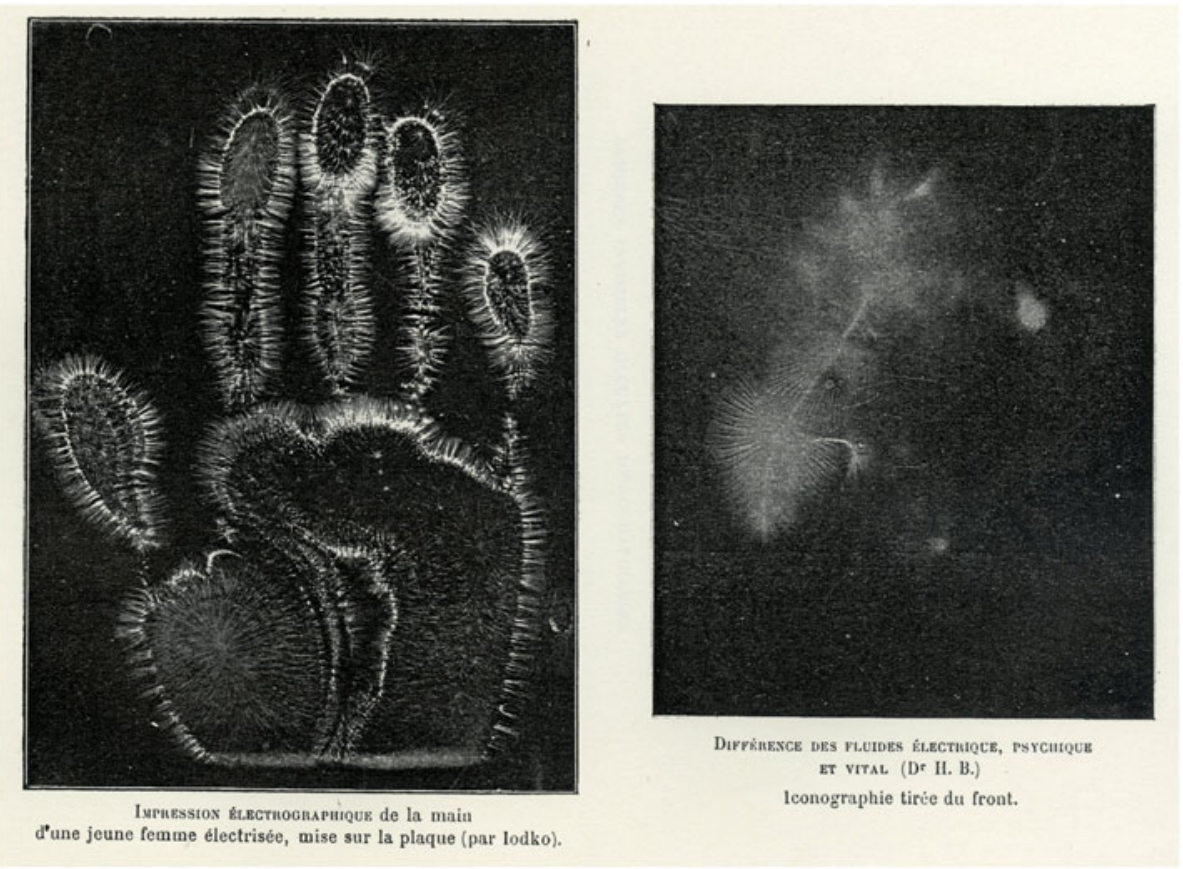

Figure 1: Hippolyte Baraduc, L'Âme humaine, ses mouvements, ses lumières et l'iconographie de l'invisible fluidique (Paris: Georges Carré, 1896), Plate XXXII; scan provided by Harvard Library.

Odic-Magnetic Emission of the Human Body, while the French neuropsychiatrist Jules Bernard Luys (1828-97) experimented with photographies des effluves (photography of fluids) at the same time. Luys produced numerous photographic plates that displayed bright radiations around the fingers of a human hand that allegedly resulted from the body's fluidic energies. ${ }^{13}$

Thus, the basic principle of fluidic photography was to expose a photographic plate to living organisms and look for the traces that the natural radiation of these bodies imprinted on the plate without any intentional control by the photographer or the photographed. But by focusing on organic radiation, fluidic photography could not 'catch' the soul itself. It was left to one of Luys' colleagues at the Salpêtriêre hospital to conduct experiments that no longer documented the fluidic energies of the body alone: the French physician Hippolyte Baraduc (1850-1902), who had a reputation for curing his patients with the help of magnetic energy, also succeeded in producing pictures of the energetic fields that radiate around the human hand (figure 1).

However, he claimed furthermore to be able to fixate visual impressions caused by intentional thoughts or mental states - such as grief in the case of a young boy who mourns his pet. The illustration shows a cloud-like shape above the boy's head that Baraduc interpreted as a material trace of the fluidic energies caused by mourning (figure 2).

In his book The Human Soul (L'Âme humaine, Paris 1896), Baraduc presented more than seventy similar photographs and referred to them as 'psychicones', that is, images

${ }^{13}$ Ibid., 127. 


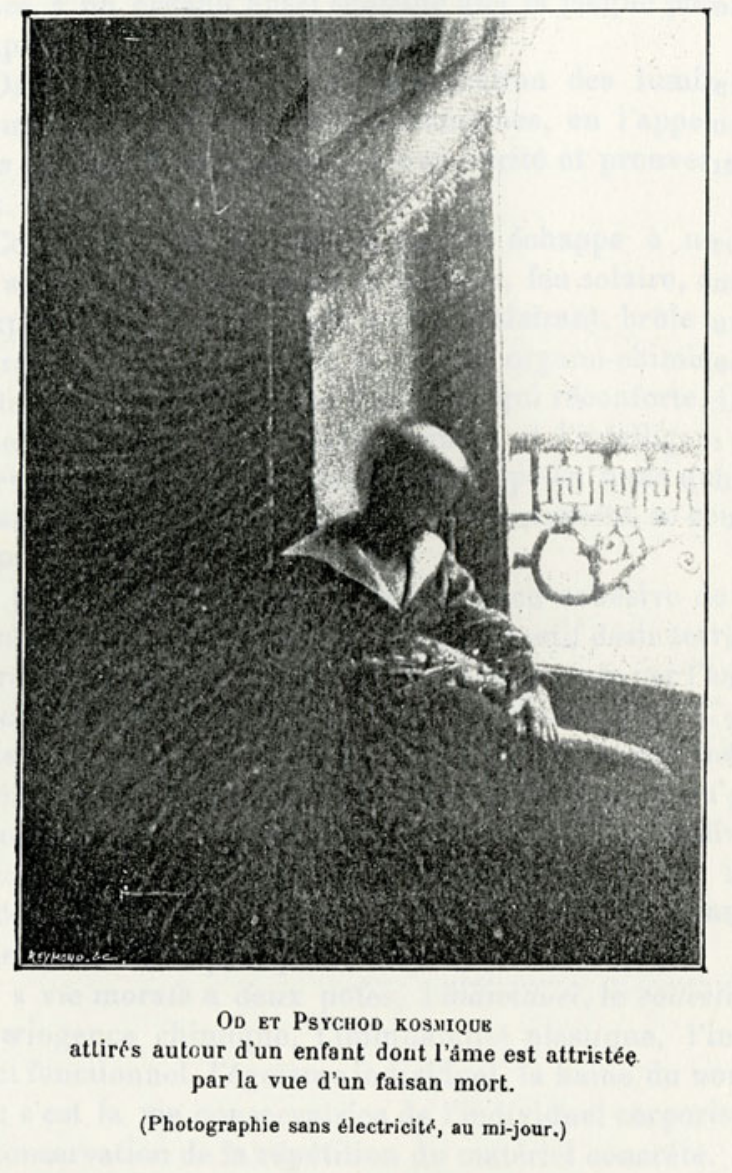

Figure 2: Hippolyte Baraduc, L'Âme humaine, ses mouvements, ses lumières et l'iconographie de l'invisible fluidique (Paris: Georges Carré, 1896), Plate XLIII; scan provided by Harvard Library.

of the soul, that he claimed were created by a 'psycho-odic-fluidic-current', to which the chemical fluid on the plates was so sensitive that they responded by the materialisation of visual shapes. ${ }^{14}$ Most of the photographic plates displayed abstract blurs so that Baraduc's contemporaries - for example, his colleague Adrien Guébhard (1849-1924) - called them erroneous. In fact, upon reviewing the psychicones, one tends to attribute the nebulous shapes rather to chance or artificial manipulation than to psychic radiation. But, as Peter Geimer argues in his recent study on Accidental Images, the existence of photographic inscriptions on the plates itself cannot be denied - regardless of the source that actually created them. Thus, Geimer points at the aspect that even a critical perspective on psychicones shares with the claim to record traces of the soul on photographic plates: 'Baraduc and Guébhard could mutually accuse each other of confusing artificiality

\footnotetext{
${ }^{14}$ Hippolyte Baraduc, The Human Soul. Its Movements, its Lights, and the Iconography of the Fluidic Invisible (Paris: Libraire internationale de pensée nouvelle, 1913 [Orig. 1897]), 12.
} 
with nature and nature with artificiality and yet share the common conviction that a recording did take place. ${ }^{15}$

It is therefore not enough to label Baraduc an unscientific occultist. On the contrary, he was an accepted member of the Salpêtriêre hospital staff, and his photographic experiments were no para-scientific side activity but a consistent continuation of his medical practice. Furthermore, he was not the only author at the turn of the twentieth century who presented critical evidence of the visibility of the soul. Louis Darget (18471921), a layman with a military career, considered Wilhelm Roentgen's discovery of XRays sufficient proof of invisible radiation and proceeded to produce thought photography (photographie de la pensée) by placing plates on the foreheads of his experimental subjects:

During the thought process, the soul causes the atoms to vibrate and the phosphor within the brain to glow. This glowing radiation is projected outside. If one focuses their thoughts on an object with simple contours such as a bottle, the fluidic thought-image emerges through the eyes and impresses the photographic plate by its radiation so that a picture is obtained. ${ }^{16}$

In Germany, Albert von Schrenck-Notzing (1862-1929), a trained physician who experimented with hypnosis in psychotherapeutic sessions, presented photographs of 'ectoplasm' that his medium Stanislawa T. produced - mysterious three-dimensional lumps that were released through various orifices. In his book on Phenomena of Materialization, Schrenck-Notzing called similar apparitions 'teleplasm' or 'ideoplasm', but he also discussed 'impressions on the photographic negative corresponding to the thought images of the medium, that is, "thought photography", ${ }^{17}$ The term was shortened to 'thoughtography' in the English translation of the experimental protocols by Japanese psychologist Tomokichi Fukurai (1869-1952), who, in 1931, presented studies of Japanese psychics who projected letters on sealed photographic plates without use of a camera. ${ }^{18}$ Fukurai also conducted experiments with the protégé of the Society for the Study of Supernormal Pictures, William Hope ${ }^{19}$, and was later rediscovered by American psychiatrist Jules Eisenbud (1908-99) who published a comprehensive case study in 1967 on the 'thoughtography' of Ted Serios, a Chicago bellhop who was able to project images of objects, faces and buildings on Polaroid film.

Research on parapsychological photography usually refers to this history from Reichenbach to Eisenbud as a continuity. ${ }^{20}$ Yet, with regard to the possibility of photographing the soul, there are important differences between representations caused by bodily fluidic energy as presented by Reichenbach, Luys and Schrenck-Notzing, as well as Baraduc's 'psychicones', that were allegedly caused by fluidic energies of the soul on the one hand, and the intentional thought photography in Darget's, Fukurai's and Eisenbud's experiments on the other. Only the latter claimed the psychic's ability to focus mental energies and intentionally produce a well-shaped and mimetic picture of a concrete

15 Peter Geimer, Bilder aus Versehen: Eine Geschichte fotografischer Erscheinungen (Hamburg: Philo Fine Arts, 2010), 156.

${ }^{16}$ Louis Darget, 'Verschiedene Methoden zur Erzielung fluido-magnetischer und spiritistischer Photographien', Übersinnliche Welt, (1911), 12.

${ }^{17}$ Richard Schrenck-Notzing, Phenomena of Materialization. A Contribution to the Investigation of Mediumistic Teleplastic (London: Trubner, 1923 [Orig. 1913]), 82.

18 Tomokichi Fukurai, Clairvoyance \& Thoughtography (London: Rider, 1931 [Orig. 1913]), 91.

${ }^{19}$ Ibid., 236.

${ }^{20}$ Sabine Flach, 'Thinking about/on Thinking: Observations on the Thought Photography of the Early Twentieth Century', Configurations: A Journal of Literature, Science, and Technology, 18, 3 (2010), 441-58. 
object. In contrast to the non-mimetic shapes by Reichenbach, Luys, and Baraduc, thought photography seems to be more concrete and precise than its predecessors.

Yet, Baraduc's work is especially important for a history of soul catchers because only the psychicones claim to visualise the energies of the soul itself:

Iconography, such as I believe to have created and exposed, is based on the direct action of the human soul acting through the hand on the plate. Since 1893 my experiments have taken place without any intermediary lense, reversing the image. Solar light is refracted in inflected foci, whilst the animistic glimmering of man, or the force of universal life [...] emerges without deviation and traces itself in its very form' ${ }^{21}$

There is no camera, no intentional focus and no mimetic representation of specific shapes in Baraduc's experiments. They are simply conducted by the constellation of a photographic plate and the experimental subject's hand which, according to Baraduc, serves the function of a relay or amplifier for psychical energies. Thus, psychicones were considered passive documents of visually abstract mental states. As such, we can locate them, epistemologically, between the fluidic images of body parts and intentional thought photography.

It is in this respect that I suggest distinguishing Baraduc's soul photography from thought photography. The latter rests on the assumption that mental imagination can be photographed, for example, when Louis Darget presents the image of Beethoven after holding a photographic plate to the forehead of a piano player or the picture of an eagle. ${ }^{22}$

Similarly, Fukurai's psychics produced imprints of Japanese letters on film. And Jules Eisenbud's sessions with Ted Serios, which were thoroughly supervised by neutral experts, resulted in over 100 representations of clearly visible objects such as cars and buildings.

Additionally, as in the case of Schrenck-Notzing's experiments on ectoplasm, Fukurai and Eisenbud were no longer interested in psychological theory. They presented case studies of individual psychics and thus rather focused on the paranormal abilities of these individuals than on the general theory of 'the Human Soul' that Baraduc claimed. Twentieth-century thought photography, in other words, was no longer interested in the soul but primarily in the existence of paranormal subjects.

Baraduc's approach was different on a number of levels. His experimental subjects illustrated a general psychological theory. Furthermore, Baraduc's photography was not based on a mimetic function but rather on the autonomous agency of the photographic plate in its interaction with more or less random light effects. Psychicones did not represent the soul as much as they presented technology: by producing large numbers of photographic plates that displayed abstract light effects, Baraduc demonstrated the immense sensitivity of the new medium as well as its ability to visualise fluidic energies that the natural human sensory apparatus was not able to pick up. Thus, photography of the soul mostly consisted of exploring technological possibilities of cameras and plates, and the shady blurs Baraduc's psychicones displayed did not imply definite data but were open to various interpretations. In other words, psychological information was generated from visual noise.

This is why the debate on the authenticity of fluidic photography is less interesting than its contribution to our understanding of the role of technology in the history of science. By attributing photographic traces to mental energies, the debate on fluidic photography established a notion of agency that operates beyond the control of the

${ }^{21}$ Baraduc, op. cit. (note 14), 32.

${ }^{22}$ Cf. Im Reich der Phantome: Fotografie des Unsichtbaren, exhibition catalogue, ed. Andreas Fischer and Veit Loers (Ostfildern, Germany: Cantz, 1997), 16. 
researcher. However, photographic technology escaped control in a similar way when it generated random and abstract pictures, that is to say, photography was a popular soul catcher because the effects it generated were as uncontrollable as the ones attributed to the soul. From this perspective, 'photography' and 'the soul' were interchangeable agents within psychological experiments.

Insofar as mental fluidity became visible only through photography, photography was the only possible physical reality of the soul. While thought photography based its claim of authenticity on the mimetic representation of the outside world, fluidic mental images were shaped by visual effects on the photographic plates. Thus, they did not represent the soul but create a concept of psychology according to the technological structure of photography.

It is therefore important to distinguish Baraduc's psychicones from their occult antecedents as well as from its parapsychological successors if one wants to grasp the genuine significance of his research. Baraduc's pictures are part of the study of the soul in a very basic sense, regardless of their actual authenticity. According to Geimer, it is too simple to call the psychicones a bluff, because the abstract shapes do refer to a 'real' source of some kind. There is a chemical reality to the visual traces on the plate regardless of their - mental or material - source: 'The question is not whether a photographic plate did in fact bring out facts or artefacts, natural or artificial appearances. The question is which conception implicitly preceded such differentiations. ${ }^{23}$

From this perspective, the existence of thought photography undercuts any attempt to distinguish between 'rational' and 'irrational' scientific methods as well as between true and false results. Instead, Geimer suggests contextualising the evaluation of fluidic and thought photography within the discursive framework of their time. This implies that thought photography is interesting still, not because it actually represents a visual image of the soul but rather insofar as it reveals certain epistemological and aesthetic aspects of photography as well as correspondences between discourses on both psychological and technological media at the beginning of the twentieth century.

\section{The Reality of Hallucination: Science and Magic}

The existence of photographic plates that bear the inscription of light effects led to various attempts of rationalisation in early twentieth-century debates. In Germany, a Bavarian chemist by the name of Ludwig Staudenmaier (1865-1933) published a book on Magic as an Experimental Science in 1912. Staudenmaier argued for the physical reality of hallucinations on the grounds of the 'reversibility of the course of nervous excitation following an increase in imaginative action'. ${ }^{24}$ While our sensory receptors usually react to extrinsic input such as light or sound by specific physical motions of the receptory organs, according to Staudenmaier, these organs are also able to produce the very same physical reactions by themselves - for example, the vibration of a membrane - and thus to actually generate light and sound.

Explicitly referring to Baraduc and Darget, Staudenmaier suggested that the 'excitation' in the brain that is caused by optical imaginations can be transported to the nerves of the eye and there transformed into waves of light that are then emitted similar to a

${ }^{23}$ Geimer, op. cit. (note 15), 156.

${ }^{24}$ Ludwig Staudenmaier, Die Magie als experimentelle Naturwissenschaft (Leipzig: Akademische Verlagsgesellschaft, 1912), 44. 
projector apparatus. To prove this method, Staudenmaier also referred to photography: 'Place a photographic plate at the spot where this image appears. In other words: project hallucinations onto a photographic plate, that is, act like a photographer who also places a plate at the spot where the convex lense of the camera obscura projects the real image' ${ }^{25}$

Staudenmaier's main goal in linking the camera to mental activity, however, was to lay the groundwork for a physical and technological understanding of the soul. In contrast to the psychiatric concept of hallucination that refers to pathological and involuntary misperceptions, the photographs that he proposed (but never took) are the result of 'wellplanned methodical hallucinations'. ${ }^{26}$

Thus Staudenmaier, who was later himself classified as mentally ill, introduced an analogy between the human nervous system and the technology of photographic projection in order to 'depathologise' the notion of hallucination. Hallucinatory imagination, according to Staudenmaier, was no sign of psychic illness but a normal capacity of every cognitive system that processes sensory information. ${ }^{27}$

A similar notion was already at the foundation of Baraduc's characterisation of the soul as 'luminous vibration'. ${ }^{28}$ As a source of energy and light, Baraduc considered the human soul an apparatus that projects images, and the photographic plate was merely an instrument for the 'fixation by the image of the invisible vibration'. ${ }^{29}$ Insofar as these images allegedly resulted from the 'luminous vibration' of the soul itself, they could be called actual psychicons - although the graphic inscription of the mental energy was mediated by the hand in Baraduc's experiments. Darget later declared this mediation unnecessary, due to the soul's immediate influence on sensitive plates, but Baraduc already implied the same potential when he wrote: 'The spirit frames an image, modulates it with human vital force, veils itself with a form, which expresses it, and is exteriorised in this form, which is graphed on the plate' ${ }^{30}$ An impressive example for this process is the photograph Baraduc took of his wife's soul that left her body twenty minutes after her death in the shape of three white clouds (figure 3).

To Baraduc, these material impressions of immaterial energies proved the continuity between scientific realism and the realm of the occult based on the physical energy of the soul:

Objectivity, that is to say, the vision for the eye of liquid forms, is a fact, which I myself have several times been able to verify. These fluidic forms, called hallucinatory or real, are animistic creations which our spirit modulates or which we receive entirely modulated by a suggestion of the here-below or by a pneumo-fluidic communion with the hereafter. ${ }^{31}$

Thus, the technology of photography visualises the physiological reality of hallucination: to hallucinate is considered a regular mental operation and - as in Staudenmaier - the issue

25 Ibid., 189.

26 Ibid., 45.

${ }^{27}$ Interestingly, this hypothesis is supported by current research in neuropsychology on the phenomenon of 'extramission': there is in fact 'connectivity' between the cognitive function of language processing and the speech mechanism that can be activated by the imagination of voices: Peter Krummenacher et al., 'Dopamine, Paranormal Belief, and the Detection of Meaningful Stimuli', Journal of Cognitive Neuroscience, 22, 8 (201), 1670-81.

${ }^{28}$ Baraduc, op. cit. (note 14), 13.

${ }^{29}$ Ibid., 31.

${ }^{30}$ Ibid., 58.

${ }^{31}$ Ibid., 54. 


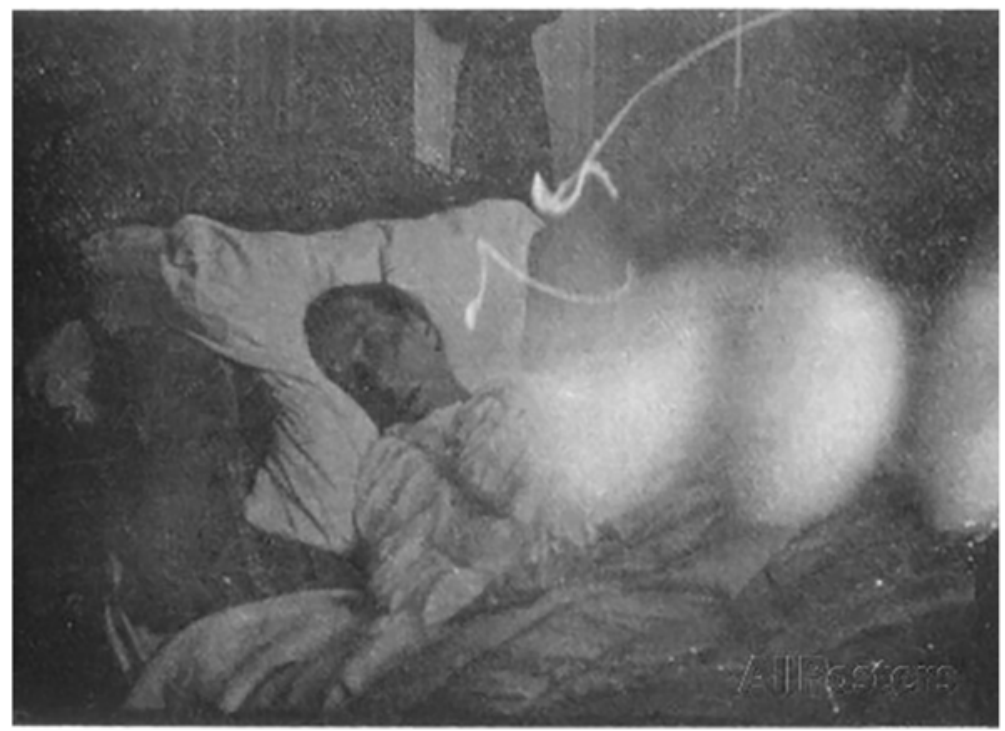

Figure 3: Hereward Carrington The Problems of Psychical Research Experiments and Theories in the Realm of the Supernormal (New York: Dodd 1921), 32; provided by University of California Libraries at http://www.ope nlibrary.org/books/OL6632228M.

is not whether they are 'true' or 'false' but simply whether they produce enough fluidic energy to be inscribed on the photographic plate.

As already mentioned, most of these photographic exteriorisations are abstract shapes and as such pose the problem of deducting an actual psychological theory from them. Baraduc referred to cosmic forces and mythological figurations - the veil of Isis, the web of Persephone, the cloak of Tanith ${ }^{32}$ - to attach significance to the seemingly random patches of light on the pictures. But these references do not weaken the strong ties between soul photography and related scientific discourses. Much in accordance with nineteenth-century occultism, Baraduc understood ancient mythology as an early knowledge of transcendent forces, but these forces were not considered to oppose the principles of rational science: insofar as photography is a technology that is in accordance with modern science, the existence of visible traces on photographic plates seemed to demonstrate the physical reality of spiritual energies.

This also applies to imaginations that contemporary psychiatry considered pathological, as the following case study from The Human Soul demonstrates:

Mme B1... is a possessed person, very fluent under the inspiration of a force called mercurial. She demands adoration for her god, who visits her, breathes upon her, completely possesses her. [...] Several doctors have diagnosed her state as that of a mad person suffering from the monomania of writing; but for me, she is an inspired larva, that is to say a fluidic possessed after the experiment quoted. [...] The larvae of Mme B1. .. were attracted on a plate producing an icone bipolarised on a positive plate which I had to have transformed into a negative plate, to have the series of negatives which I here present. ${ }^{33}$

Baraduc does not define precisely what he refers to by 'larva' her, but the strategy of his argument is obvious: where academic medicine diagnoses a pathological state of mind, the

32 Ibid., 111.

33 Ibid., 139. 


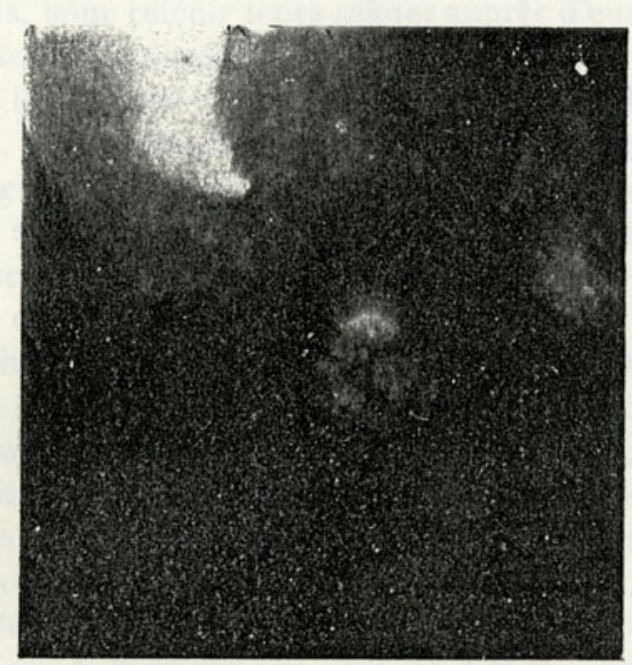

Évocatiox et accolplement aximece.

(Avec électricité, sans appareil, arec la main.)

Figure 4: Hippolyte Baraduc, L'Âme humaine, ses mouvements, ses lumières et l'iconographie de l'invisible fluidique (Paris: Georges Carré, 1896), Plate L; scan provided by Harvard Library.

psychology of fluids detects visible traces of mental energies (figure 4). Baraduc's caption to plate L vividly displays his method of interpreting the abstract dots and shapes on a plate as concrete phenomena: while professional doctors only observe Mme. Bl.'s behaviour and label it as a sign of madness, photography reveals that she is simply a person with an especially sensitive and energetic soul - and thus not ill but clairvoyant.

But the same method is also applicable to general emotional states such as mourning that are visually recorded on a photographic plate, for example, the clouds above a boys head that are to be interpreted as a visual deposit of his mental state of mourning in the case of the young boy referred to earlier (figure 1).

Again, this example shows that the abstract appearance of psychic energies is no disadvantage for scientific evaluation. On the contrary: mental states such as mourning do not have a known or established visual shape such as the specific posture of the body that can be interpreted as an expression of mourning. Therefore, the amorphous 'real tissue of vital fluid' at the top of the picture can be attributed to sadness merely because it is visible, not because it depicts 'sadness' in a mimetic or allegorical way (as represented by the boy's bent head). Psychicones are images of the soul only as long as they remain as abstract as the soul.

\section{The Aesthetics of Soul Photography: Theories of Abstraction in Psychology and Art}

That is why the evaluation of the pictures has to move beyond the distinction of 'real' and 'fake' or 'science' and 'fallacy'. Instead, there is a third and final dimension 
soul photography is connected to that I am going to briefly turn to in the closing paragraphs: the abstract character of the pictures as well as the autonomous agency of the technological device both bear resemblance to new trends in early twentieth-century avant-garde art. Insofar as a large portion of avant-garde art repositioned the source of artistic production from intentional subjectivity to unconscious impulses, it shared an interest in the automatic production of visual traces with the experiments in fluidic photography. Based on this mutual interest, the avant-garde discourse within aesthetic theory and practice, too, avoids any dichotomy between 'scientific psychology' and 'irrational occultism' by acknowledging the technological autonomy of both photography and artistic representation. Thus, while the abstraction of Baraduc's psychicones suffered from a lack of information according to empirical psychologists of the time, they provided all the more insights for an artistic approach.

This connection was noted at the time by readers such as German spiritist Friedrich von Feerhow (aka Friedrich Wehofer, 1888-1921) who had published several treatises on Reichenbach's 'Od' as well as on Walter John Kilner's theory of 'Aura' in the early twentieth century. In his book, The Photography of Thought, published in 1928, Feerhow suggested to use the term 'psychography' to account for materialisations of the 'plastically formed psychic substance' ${ }^{34}$ itself. This material side of mental activities was called 'psychogon', and Feerhow claimed that under certain circumstances this psychogon became visible in the shape of a coloured cloud in front of a psychically active person. Thus, photography could be considered a way to prove the reality of these apparitions:

If psychogons that have been only visible to clairvoyants so far can be proven to be real with the help of technical devices, the physiological regime that reduces the 'mechanics of mental life' to the interplay of neurons will naturally come to an end. The entire psychical life, our whole notion of mental activities will obtain a new foundation and psychological research will take on a new direction. ${ }^{35}$

Feerhow's argument aimed at the epistemological and institutional consequences of photography for psychology: the study of the human soul was reduced to physiological research by the empirical and rational approaches of the late nineteenth and early twentieth centuries. To become an actual psycho-logy again, this physiological approach had to be replaced by the demonstration of the reality of the soul itself. The traditional distinction of body and mind that considered the latter an abstract entity ignored the physical reality of electric radiation of the brain as well as the ability of this radiation to trigger chemical reactions on the plate.

Feerhow presented a number of photographs from Baraduc's The Human Soul to illustrate his argument. However, since they are black and white pictures, these examples could not support the theory of the psychogon's different colours. Feerhow therefore referred to another source, Annie Besant (1847-1933) and Charles Webster Leadbeater's (1854-1934) book on Thought-Forms from 1901 that suggested various colours for emotional states such as love (red), spirituality (blue), and malice (black) and claimed that these mental states expressed themselves in colours. In a similar way Feerhow claimed visibility for the psychogon. Besant and Leadbeater wrote:

The mental body is an object of great beauty, the delicacy and rapid motion of its particles giving it an aspect of living iridescent light, and this beauty becomes an extraordinarily radiant and entrancing loveliness as the

${ }^{34}$ Friedrich Feerhow, Die Photographie des Gedankens oder Psychographie: Eine Studie über die Natur der Psychogone und die bisherigen Versuche von Psychogrammen ('Gedankenphotographie') (Leipzig: Altmann, 1913), 50.

35 Ibid., 48. 


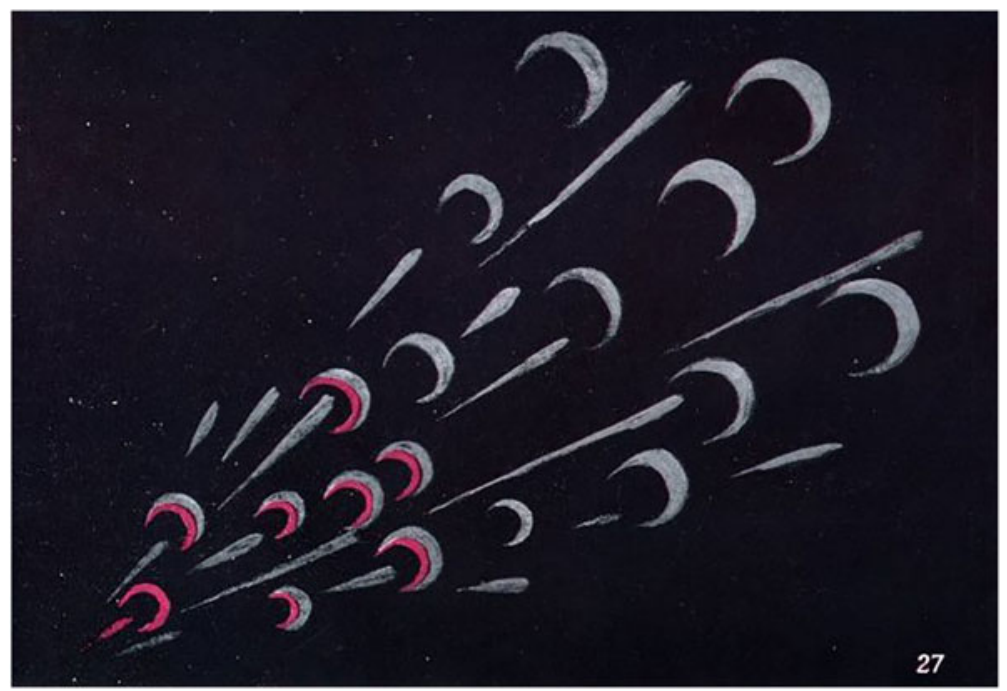

Figure 5: Annie Besant and Charles W. Leadbeater, Thought-Forms (London: Theosophical Publishing Society, 1901), Figure 27; available for re-use under a CC-BY-SA licence at http://digi.ub.uni-heidelberg.de/diglit/besant 1905/0068?sid=9c32303d6c3bc8977f0c97de03e595df

intellect becomes more highly evolved and is employed chiefly on pure and sublime topics. Every thought gives rise to a set of correlated vibrations in the matter of this body, accompanied with a marvellous play of colour, like that in the spray of a waterfall as the sunlight strikes it, raised to the $n$th degree of colour and vivid delicacy. The body under this impulse throws off a vibrating portion of itself, shaped by the nature of the vibrations - as figures are made by sand on a disk vibrating to a musical note - and this gathers from the surrounding atmosphere matter like itself in fineness from the elemental essence of the mental world. We have then a thought-form pure and simple, and it is a living entity of intense activity animated by the one idea that generated it. If made of the finer kinds of matter, it will be of great power and energy, and may be used as a most potent agent when directed by a strong and steady will. ${ }^{36}$

Besant and Leadbeater, too, refer to Baraduc here and emphasise that photography has proven to be 'most interesting and valuable as forming a link between clairvoyant and physical scientific investigations'. However, to obtain colourful depictions of psychic energies, they had to colourise one of Baraduc's psychicons that displays how 'an eruption of broken circles resulted from sudden annoyance' (figure 5).

Baraduc's original psychicone, in contrast, looked like figure 6.

All the other plates that illustrated the argument of colourful thought-forms were handmade paintings, for example, of 'vague pure affection' (figure 7),

or of the 'greed for drink' (figure 8).

Obviously, Besant and Leadbeater's 'psychicons' are no longer photographic, and their close connection to avant-garde art, such as the paintings of Wassily Kandinsky (18661944) who studied Leadbeater's theory of colours, has often been noted. ${ }^{37}$

36 Annie Besant and Charles W. Leadbeater, Thought-Forms (London: Theosophical Publishing Society, 1901), 33.

${ }^{37}$ Sixten Ringbom, The Sounding Cosmos: A Study in the Spiritualism of Kandinsky and the Genesis of Abstract Paintings (Helsingfors: Abo Akademi, 1970); Wolfgang Hagen, 'Der Okkultismus der Avantgarde um 1900', in Sigrid Schade and Georg Christoph Tholen (eds), Konfigurationen: Zwischen Kunst und Medien (Munich: Fink, 1999), 339-57. 


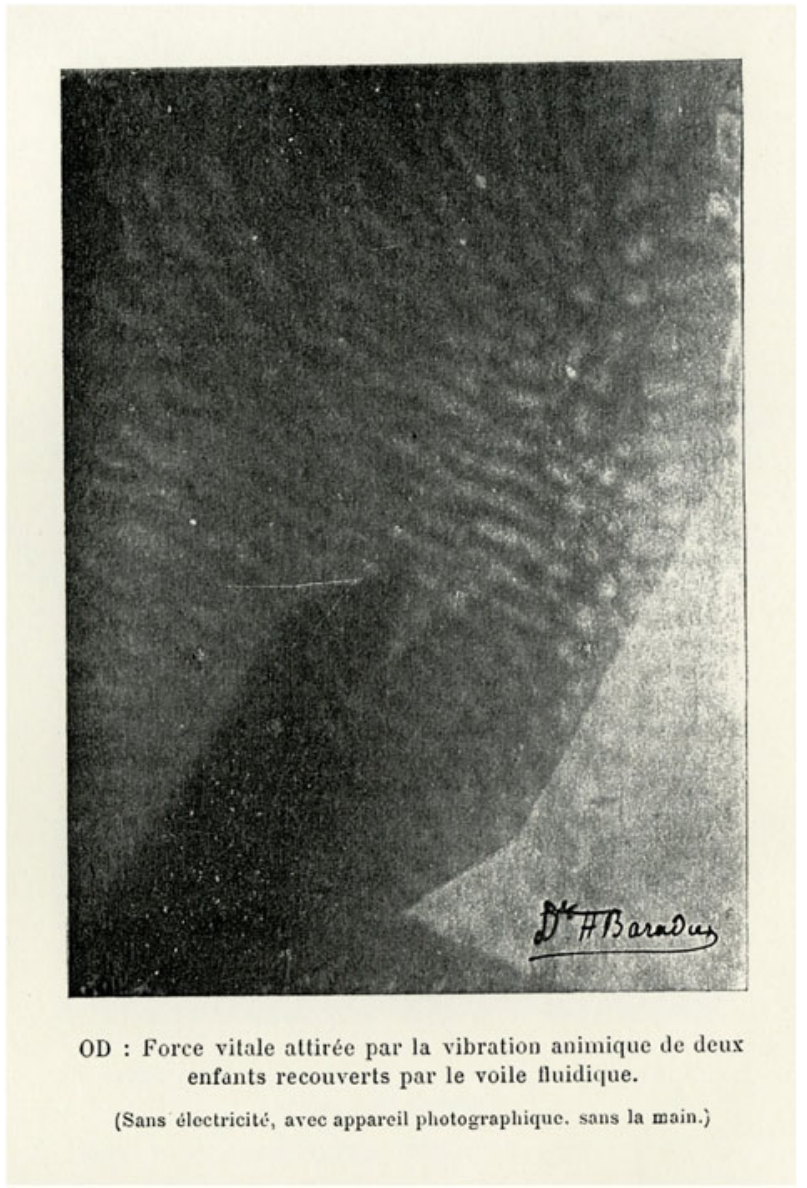

Figure 6: Hippolyte Baraduc, L’Âme humaine, ses mouvements, ses lumières et l'iconographie de l'invisible fluidique (Paris: Georges Carré, 1896), Plate II; scan provided by Harvard Library.

Upon reading an article on transcendental photography in the German Journal of the Extrasensory World in 1908, Kandinsky developed an aesthetic theory that aimed at replacing mimetic representation of the external physical world by the immediate recording of 'spiritual vibration', as Kandinsky called it in his essay Concerning the Spiritual in Art in 1912: 'form-harmony must rest only on a corresponding vibration of the human soul'. ${ }^{38}$

Thus, the principle of manufacturing photography from Baraduc's laboratory becomes an artistic procedure. While Besant and Leadbeater transformed psychiconic photography

${ }^{38}$ Wassily Kandinsky, Concerning the Spiritual in Art, trans. M.T.H. Sadler (New York: Dover, 1977), 24 and 26. Cf. exhibition catalogues ed. Christoph Wagner, Das Bauhaus und die Esoterik (Bielefeld/Leipzig 2005), and Veit Loers, Okkultismus und Avantgarde: Von Munch bis Mondrian (Frankfurt 1995). Cf. Wassily Kandinsky: Linie - Das Langformat begünstigt die Gesamtspannung der wenig gespannten Einzelformen. Punkt und Linie zu Fläche. Beitrag zur Analyse der malerischen Elemente (Munich: Albert Langen, 1926), 168f., as well as Wassily Kandinsky, Concerning the Spiritual in Art, translated by M.T.H. Sadler, Dover 1977, 24 and 26. Cf. the exhibition catalogues by Christoph Wagner (ed.), Das Bauhaus und die Esoterik (Bielefeld/Leipzig 2005) and Veit Loers (ed.), Okkultismus und Avantgarde. Von Munch bis Mondrian (Frankfurt 1995). 


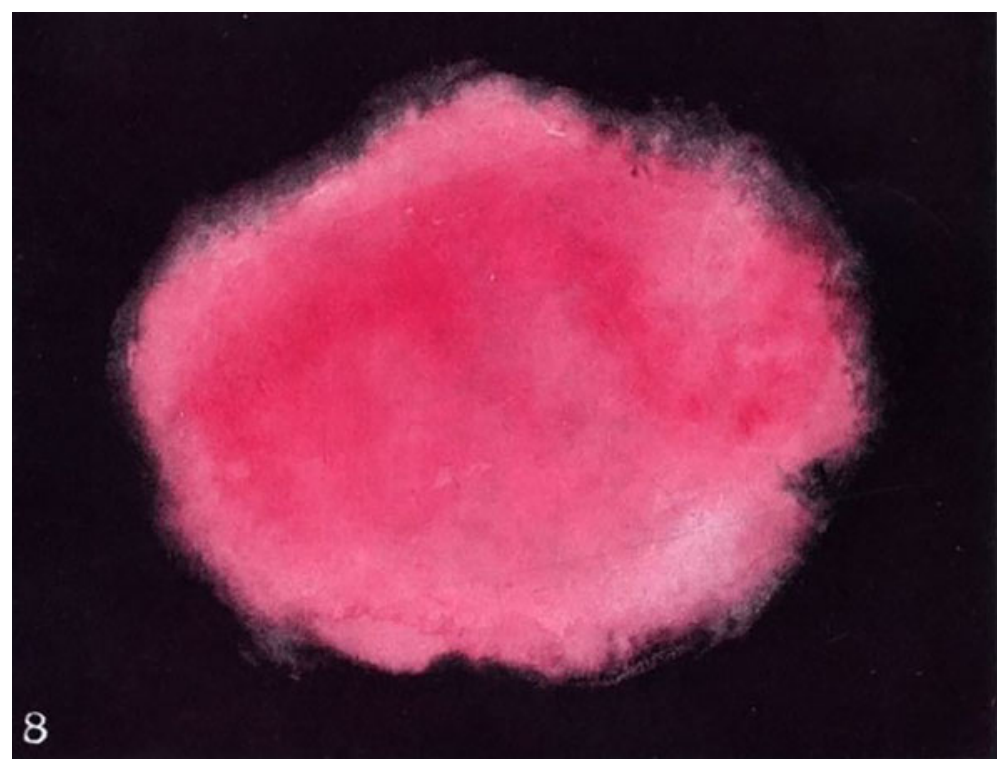

Figure 7: Annie Besant and Charles W. Leadbeater, Thought-Forms (London: Theosophical Publishing Society, 1901), Figure 8; available for re-use under a CC-BY-SA licence: http://digi.ub.uni-heidelberg.de/diglit/besant19 05/0044? sid=9c32303d6c3bc8977f0c97de03e595df.

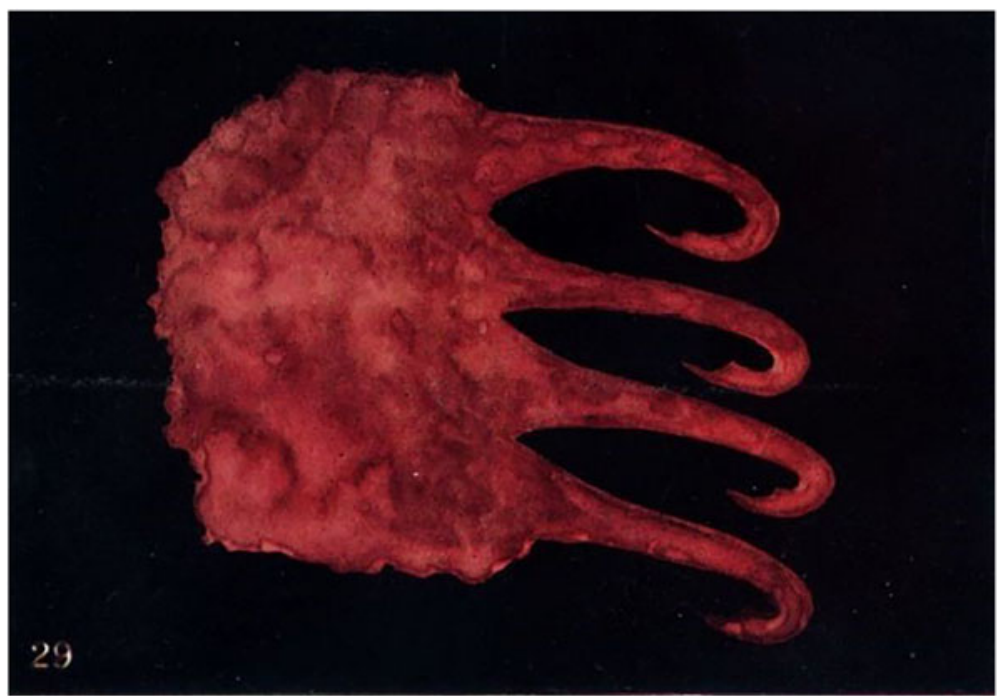

Figure 8: Annie Besant and Charles W. Leadbeater, Thought-Forms (London: Theosophical Publishing Society, 1901), Figure 29; available for re-use under a CC-BY-SA licence: http://digi.ub.uni-heidelberg.de/diglit/besant1 905/0071?sid=9c32303d6c3bc8977f0c97de03e595df.

into the abstract shapes and shadings of their paintings, Kandinsky used these 'scientific' representations of thought-forms for his rendition of abstract art.

In accordance with this mutual exchange, Feerhow even envisioned the use of thought photography in art at the end of his treatise when he announced: 'the whole tiresome 
storehouse of canvas, palette, brush, and paint daubing will be superfluous, and in the few enthusiastic minutes of fixation the most colourful artwork will be begotten as well as born, living, as it was conceived in the same instance from imagination'. ${ }^{39}$

According to this emphatic coda, psychological photography will not only revolutionise science, it will also create new artistic forms insofar as artistic imagination is also one of the mental activities of the human soul and as such, every handmade artwork is but a poor copy of the original imagination's actual psychogon. Feerhow's enthusiasm easily ignored the limitations to photographic colorisation at his time, but his prediction was not as much wide of the mark as it may seem. Within the surrealistic movement of French literature in the 1920s and 1930s, for example, the autonomous production of abstract shapes was indeed considered as an immediate expression of mental processes attributed to the subconscious.

In his essay The Automatic Message, first published in 1933, André Breton (18961966), who had previously established the surrealist method of automatic writing in order to gain poetic access to the subconscious, expanded this concept of spontaneous production to visual phenomena. Breton focuses on mediumistic drawing, not photography. However, insofar as he opposed the notion of active and intentional projections in spiritualist drawing sessions and favoured the passive receptivity of the psychic medium, ${ }^{40}$ Breton sided with Baraduc's notion of spontaneous and abstract psychicones rather than Darget's theory of thought photography: instead of claiming the external reality of hallucination, Breton's concept of surrealist writing and drawing was about 'the most private and interior revelation'. ${ }^{41}$

To fully unfold the role subconscious image production plays within the surrealistic movement would exceed the limits of this paper and lead us too far from the actual topic of soul photography - although photography played an important role in Breton's novel Nadja, published in 1928, and his definition of a 'psychic automatism' in the First Surrealist Manifesto, four years earlier, referred to the autonomous agency that the soul shares with photography. According to this manifesto, the writer had to reduce his rational awareness in order to intensify his pen's sensitivity to subconscious impulses and energies - that were thus supposed to emerge from the soul immediately onto the paper, composing words that to the reader seemed as abstract and random as the visual traces on Baraduc's plates.

Thus, attributing aesthetic trends towards abstraction and automatic production within the European avant-garde movement of art and literature to the specific implications of Baraduc's soul photography sufficiently emphasises the autonomous role of the 'catcher' in the process of 'soul catching'. It is precisely because the soul is beyond representation that photography could unfold an aesthetic potential under the pretence of psychological research. Regardless of the scientific value of this research, the aesthetic dimension of abstraction and automatisation was of lasting influence on twentieth-century culture. It is in this influence that the 'truth' of soul photography lies.

${ }^{39}$ Feerhow, op. cit. (note 34), 51.

${ }^{40}$ Katharine Conley, 'Surrealism and Outsider Art: From the 'Automatic Message' to André Breton's Collection', Yale French Studies, 109 (2006), 129-43: 131.

${ }^{41}$ Ibid., 143. 